\title{
قائمة المحتويات
}

$14-13$

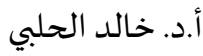

كلمـة العـدد

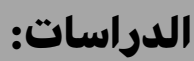

د. أحمد عبد الحميد حسين صالح 38 - 15 38

94-39

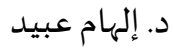

د/ فوزي علي عبد الرحمن الزامل

$134-95$

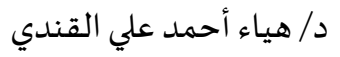

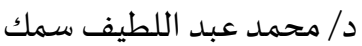

160-135

الشيماء السيد محمود محمد

د. أحمد سعد الدين بسيوني 198-

مصطفى محمد إبراهيم الهلالي 199-226

د. سميرة أحمد فهي عبد الغنى 244-22

247-245
برمجيات تحقيق النزاهة العلمية في الإنتاج الفكري مع التخطيط لتطوير برنامج عربي تجيقي • تقييم المكتبات الرقميـة الأكاديميـة العربية: منـاهج ومقاييس التقييم من وجهة نظر المستفيدين

• كفــاءة العمليـة التدريسـية للمقـررات التطبيقيـة بمنصـات التعليم عـن بعـد: دراسـة تطبيقيـة لعـدد من مقررات التصميم الداخلي • منصــات المقـررات الإلكترونيـة في مجـال المكتبـات والمعلومات: دراسة تخطيطية • البيانات الضخمة في المكتبات: الماهية والأهمية • التحــول الرقمـي في عصــر البيانـات الضـخممة: مراجعة علمية

\section{عروض الكتب والرسائل الجامعية:}

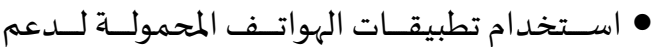
خــدمات مكتبــات المتــاحف الأثريـة في القــاهرة الكبرى: دراسـة تحليلية تطبيقية

\section{تقارير المؤتمرات}

• اجتمـاع الخبراء ضـمن مراحل مشـروع "تعزيز دور تكنولوجيا المعلومات والاتصيالات في صهون وإتاحسة الوصـول للتيراث الوثائقي الرقمي من أجلـ التنميـة

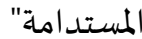




\section{English Section}

13-7

- English abstracts 